\title{
IMPLEMENTASI LOGIKA FUZZY PADA SISTEM MONITORING SUHU TERNAK AYAM PETELUR BERBASIS WEB
}

\author{
Cavin Yohanes Oraplean, Joseph Dedy Irawan, Deddy Rudhistiar \\ Program Studi Teknik Informatika S1, Fakultas Teknologi Industri \\ Institut Teknologi Nasional Malang, Jalan Raya Karanglo km 2 Malang, Indonesia \\ cavinyohanesoraplean@gmail.com
}

\begin{abstract}
ABSTRAK
Monitoring suhu memiliki peranan penting pada ternak ayam petelur. Dengan adanya sistem monitoring, maka pemantauan suhu dan kelembaban dapat dipermudah baik dari segi waktu maupun dalam segi kinerja. Sistem ini terdiri dari berberapa komponen seperti, DHT11 sebabai sensor suhu dan kelembaban, BH1750 sebagai sensor intensitas cahaya, kipas pendingin, pemanas dan menggunakan NODEMCU. Sistem ini menggunakan Logika Fuzzy untuk menentukan output dari kipas pendingin dan pemanas. Apabila sistem mengidentifikasi suhu diatas keadaan normal maka pendingin mati, dan apabila suhu dibawah keadaan normal maka pemanas akan mati. Hasil yang diperoleh pada pengujian fungsional adalah sistem dapat berjalan dengan baik pada beberapa browser. Hasil yang diperoleh dengan melakukan beberapa uji coba pada sensor DHT11 tingkat akurasi sensor DHT11 ini sebesar 98.7174\% dengan rata-rata error sebesar $1.2833 \%$, dan dari 25 kali percobaan yang dilakukan pada logika fuzzy memiliki tingkat akurasi sebesar 100\%. Hasil yang diperoleh dengan melakukan 10 kali percobaan pada sensor BH1750 memiliki tingkat sebesar 98.0652\% dan rata-rata error sebesar $1.9348 \%$.
\end{abstract}

Kata Kunci: Sistem Monitoring, DHT11, BH1750, Logika Fuzzy, NODEMCU

\section{PENDAHULUAN}

Seiring dengan Perkembangan yang semakin pesat, penggunaan komputer memegang peranan penting dalam berbagai bidang yang saling mendukung dalam aspek kehidupan. Termasuk didalamnya sistem monitoring. Dengan adanya sistem monitoring, maka kegiatan dapat dipermudah baik dari segi waktu maupun dalam segi kinerja.

Dalam hal memonitoring suhu ruangan pada ternak ayam terdapat sedikit permasalahan yaitu Menurut Wulan Sari dan Ika Ayu. (2020) Suhu yang tinggi dapat memicu stress dan dapat mengakibatkan kematian pada anakan ayam dan suhu yang terlalu rendah dapat mempengaruhi ukuran telur saat ayam sudah dewasa sehingga suhu kandang ayam petelur yang berusia $8-14$ harus dijaga pada suhu $28^{\circ} \mathrm{C}-30^{\circ} \mathrm{C}$ dan kelembaban 55\%-60\%. [1]

Menurut Erfan Kustiawan dkk. (2019) Intensitas pencahayaan juga dapat mempengaruhi produksi telur dengan pencahayaan dibawah 15 lux akan menghasilkan telur yang lebih besar jika dibandingkan dengan intensitas pencahayaan diatas 15 lux. [2]

Sistem yang digunakan saat ini menggunakan sistem manual dalam pengecekan suhu ruangan, sehingga pemilik sering bolak-balik memantau suhu pada kandang ternak ayam sehingga membutuhkan upaya yang lebih dan juga mengurangi efisiensi dari segi waktu, maka dengan adanya sistem monitoring ini dapat diharapkan akan lebih mempermudah pekerjaan manusia di mana komputer dibutuhkan untuk memonitoring kendang sehingga penggunaan waktu lebih efisien.
Dari uraian yang disampaikan diatas, maka di buatlah sistem yang dapat mendeteksi suhu ruangan. Sistem dilengkapi dengan sensor DHT11,yang di mana DHT11 dengan menggunakan metode Fuzzy Logic yang berfungsi untuk mendeteksi suhu setiap beberapa detik sekali pada ruangan tersebut.

\section{TINJAUAN PUSTAKA}

\subsection{Penelitian Terdahulu}

Penelitian mengenai pendeteksian suhu pada ternak ayam broiler telah dilakukan oleh Rizky Fahmin Kafafi (2019). Dalam penelitiannya, melakukan pendeteksi suhu menggunakan DHT11 sebagai sensor suhu dan kelembaban. Dengan adanya alat alat ini, akan mempermudahkan peternak untuk mengecek suhu kandang sewaktu waktu bila diperlukan. Peternak juga di mudahkan jika ingin mengubah suhu kapan saja jika keadaan di luar kemampuan pengamatan system[3].

Kemudian Putri Huriati, Aldo Erianda, ST, MT, Fazrol Rozi, M.Sc (2020) yang merancang Aplikasi Monitoring Perkembangan Ayam Petelur Berbasis Android. Dalam penelitiannya, melakukan monitoring suhu dengan menggunakan sensor DHT11 sebagai sensor suhu dan kelembaban. Sistem inidapat memonitoring perkembangan ayam petelur dan kandang. Mulai dari aktif atau tidaknya ayam tersebut berproduksi, dan perubahan-perubahan suhu, kelembaban dan pemberitahuan jika terjadi hujan[4].

Kemudian Ery Murniyasih, Armin Lawi, Wardi (2017) yang merancang Sistem Penjualan Online dan Monitoring Otomatis Telur Ayam Ras Petelur. Dalam penelitiannya, melakukan monitoring dengan 
menggunakan sensor LDR untuk mendeteksi telur yang diproduksi[5].

Kemudian Arief Budi Laksono (2017) yang merancang sistem Pemberian Pakan Ayam serta Monitoring Suhu dan Kelembaban Kandang berbasis Atmega328. Dalam penelitiannya, melakukan monitoring dengan menggunakan sensor DHT11 yang berfungsi sebagai pendekteksi suhu dan kelembaban yang ada dalam kandang ayam, dan menggunakan lampu untuk penerangan dan meningkatkan suhu dalam kandang ayam.[6]

\subsection{Pengertian Sistem Monitoring}

Sistem monitoring atau sistem pemantauan adalah upaya sistematis untuk menetapkan kinerja standar pada perencanaan untuk merancang sistem umpan balik informasi, untuk membandingkan kinerja aktual dengan standar yang telah ditentukan, untuk menentukan apakah telah terjadi penyimpangan, dan untuk mengambil tindakan perbaikan yang diperlukan memastikan bahwa semua perusahaan atau sumber daya organisasi telah digunakan secara efektif dan seefisien mungkin untuk mencapai tujuan perusahaan atau organisasi. [7]

\subsection{Sensor DHT11}

DHT11 adalah salah satu sensor yang dapat mengukur dua parameter lingkungan sekaligus, yaitu suhu dan kelembaban udara (humidity). Dalam sensor ini ada thermistor tipe NTC (koefisien temperatur negatif) untuk mengukur suhu, sensor kelembaban tipe resistif dan mikrokontroler 8-bit yang memproses kedua sensor dan mengirim hasilnya ke pin output dengan kawat tunggal dua arah format.Jadi meskipun terlihat kecil, DHT11 ini ternyata melakukan fungsi yang cukup kompleks. Kita hanya mengambil output, lalu masukan ke sistem.[8] Sensor DHT11 ditunjukkan pada Gambar 1.

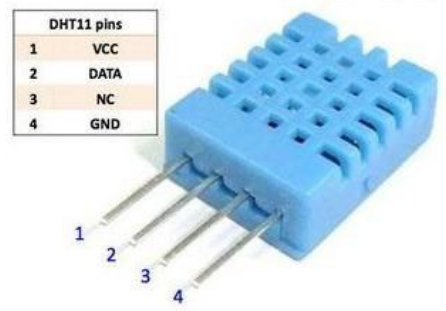

Gambar 1. Sensor DHT11

\subsection{Relay}

Relay adalah alat komponen alat / listrik yang digunakan untuk mengoperasikan satu set kontak saklar, dengan memanfaatkan listrik sebagai sumber energi. Dengan memanfaatkan Coil (koil) besi yang mengalir arus listrik, tentu akan menghasilkan medan magnet pada apa yang berakhir dengan inti besi jika koilnya listrik. Medan magnet / energi magnetik digunakan untuk melakukan sakelar nanti [8]. Gambar relay ditunjukkan pada Gambar 2.

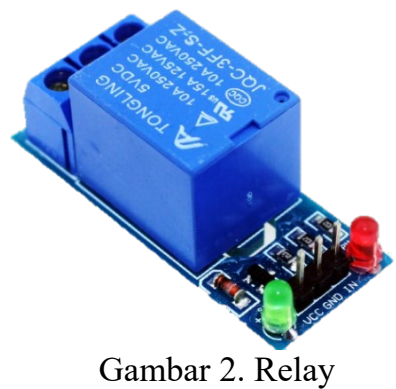

\subsection{NODEMCU}

NODEMCU merupakan platform IoT open source berbiaya rendah yang awalnya termasuk pada bagian ESP8266 Wi-Fi SoC dari Espressif Systems, dan perangkat keras yang didasarkan pada modul ESP-12. Nodemcu memiliki paket ESP8266 menjadi papan kompak dengan berbagai fitur seperti mikrokontroler + kemampuan akses terhadap wifi serta chip komunikasi USB ke serial. Jadi untuk memprogram itu hanya membutuhkan ekstensi kabel data USB yang tepat yang digunakan sebagai kabel data dan kabel pengisian smartphone Android. NODEMCU ditunjukkan pada Gambar 3.

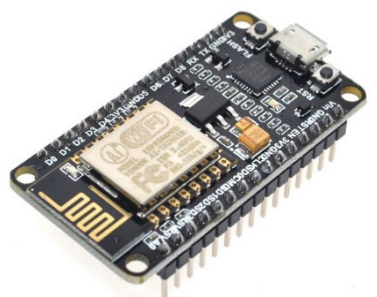

Gambar 3. NODEMCU

\subsection{XАMPP}

XAMPP adalah aplikasi server web instan dan lengkap karena semua yang Anda butuhkan untuk membuat situs web dengan sistem manajemen konten (Joomla) dapat dicoba dalam aplikasi ini. XAMPP adalah paket installer AMP (Apache, MySQL, dan PHP) yang sangat mudah untuk diterapkan di komputer Anda yang tidak memiliki server untuk dapat melihat situs yang Anda buat menggunakan bahasa server dan database server[9]. XAMPP ditunjukkan pada gambar 4 .

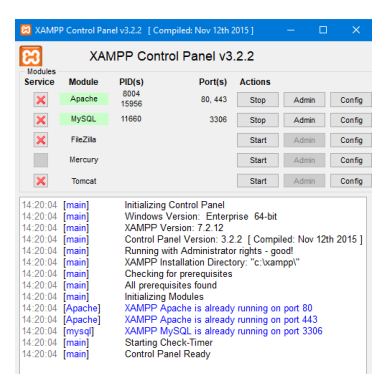

Gambar 4. XAMPP 


\subsection{Ayam Petelur}

Menurut Wiharto (2002) ayam petelur adalah ayam-ayam betina dewasa yang dipelihara khusus untuk diambil telurnya. Suprijatna (2005) menyatakan bahwa ayam pada awalnya berasal dari ayam hutan liar yang ditangkap dan dipelihara, serta dapat bertelur cukup banyak. Amrullah (2004) menyatakan bahwa ayam petelur merupakan ayam yang dipelihara dan diseleksi khususnya untuk menghasilkan telur. [2]

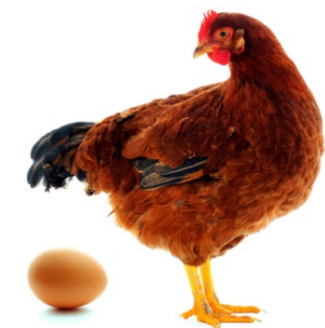

Gambar 5. Ayam Petelur

\section{METODE PENELITIAN}

Dalam penelitian ini mengimplementasi logika fuzzy untuk menentukan lamanya waktu penghidupan kipas atau pemanas. Dalam logika fuzzy ini terdapat 2 input, yaitu suhu (ingin, sejuk, normal, hangat, panas) dan kelembaban (sangat kering, kering, normal, lembab, sangat lembab.

\subsection{Logika Fuzzy}

Penerapan logika fuzzy pada kipasa dan pemanas yang terletak pada program arduino yang akan mengeluarkan output sesuai dengan rule yang sudah ditetapkan.

a. Rule

[R1] Jika suhu dingin dan kelembaban sangat kering maka kipas mati dan pemanas nyala sebentar

[R2] Jika suhu sejuk dan kelembaban sangat kering maka kipas mati dan pemanas nyala sebentar

[R3] Jika suhu normal dan kelembaban sangat kering maka kipas nyala sebentar dan pemanas mati

[R4] Jika suhu hangat dan kelembaban sangat kering maka kipas nyala sedang dan pemanas mati

[R5] Jika suhu panas dan kelembaban sangat kering maka kipas nyala sedang dan pemanas mati

[R6] Jika suhu dingin dan kelembaban kering maka kipas mati dan pemanas nyala sebentar

[R7] Jika suhu sejuk dan kelembaban kering maka kipas mati dan pemanas nyala sebentar

[R8] Jika suhu normal dan kelembaban kering maka kipas nyala sebentar dan pemanas mati

[R9] Jika suhu hangat dan jelembaban kering maka kipas nyala sedang dan pemanas mati

[R10] Jika suhu panas dan kelembaban kering maka kipas nyala lama dan pemanas mati

[R11] Jika suhu dingin dan kelembaban normal maka kipas mati dan pemanas nyala lama

[R12] Jika suhu sejuk dan kelembaban normal maka kipas mati dan pemanas sebentar

[R13] Jika suhu normal dan kelembaban normal maka kipas mati dan pemanas mati

[R14] Jika suhu hangat dan kelembaban normal maka kipas nyala sedang dan pemanas mati
[R15] Jika suhu panas dan kelembaban notmal maka kipas nyala lama dan pemanas mati

[R16] Jika suhu dingin dan kelembaban basah maka kipas mati dan pemanas nyala lama

[R17] Jika suhu sejuk dan kelembaban basah maka kipas mati dan pemanas nyala sedang

[R18] Jika suhu normal dan kelembaban basah maka kipas mati dan pemanas nyala sebentar

[R19] Jika suhu hangat dan kelembaban basah maka kipas nyala sedang dan pemanas mati

[R20] Jika suhu panas dan kelembaban basah maka kipas sedang dan pemanas mati

[R21] Jika suhu dingin dan kelembaban sangat basah maka kipas mati dan pemanas nyala sedang

[R22] Jika suhu sejuk dan kelembaban sangat basah maka kipas mati dan pemanas nyala sebentar

[R23] Jika suhu normal dan kelembaban sangat basah maka kipas mati dan pemanas nyala sedang

[R24] Jika suhu hangat dang kelembaban sangat basah maka kipas nyala sebentar dan pemanas mati

[R25] Jika suhu panas dan kelembaban sangat basah maka kipas nyala sedang dan pemanas mati

b. Grafik keanggotaan suhu

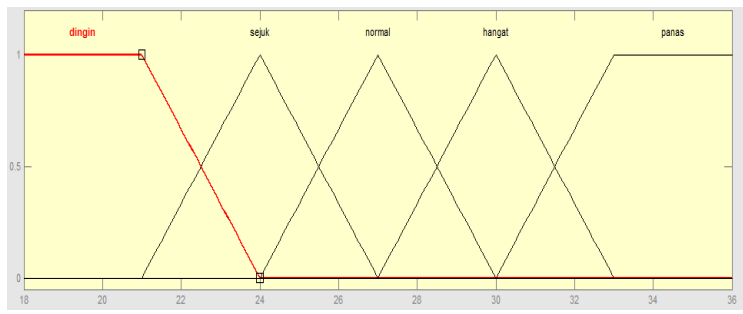

Tabel 1. Grafik Keanggotaan suhu

\begin{tabular}{|c|c|c|}
\hline No & Kondisi & Derajat $\left({ }^{\circ} \mathrm{C}\right)$ \\
\hline 1 & Dingin & $0-24$ \\
\hline 2 & Sejuk & $21-27$ \\
\hline 3 & Normal & $24-30$ \\
\hline 4 & Hangat & $27-33$ \\
\hline 5 & Panas & $30-40$ \\
\hline
\end{tabular}

c. Grafik keanggotaan kelembaban

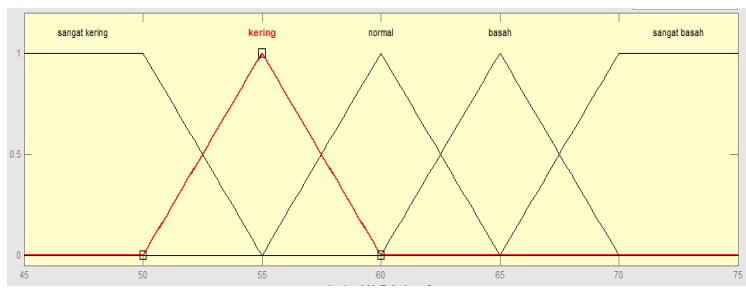

Tabel 2. Grafik keanggotaan kelembaban

\begin{tabular}{|c|c|c|}
\hline No & Kondisi & Derajat $\left({ }^{\circ} \mathrm{C}\right)$ \\
\hline 1 & Sangat kering & $0-50$ \\
\hline 2 & Kering & $50-60$ \\
\hline 3 & Normal & $55-65$ \\
\hline 4 & Lembab & $60-70$ \\
\hline 5 & Sangat lembab & $65-70$ \\
\hline
\end{tabular}


d. Grafik keanggotaan kipas

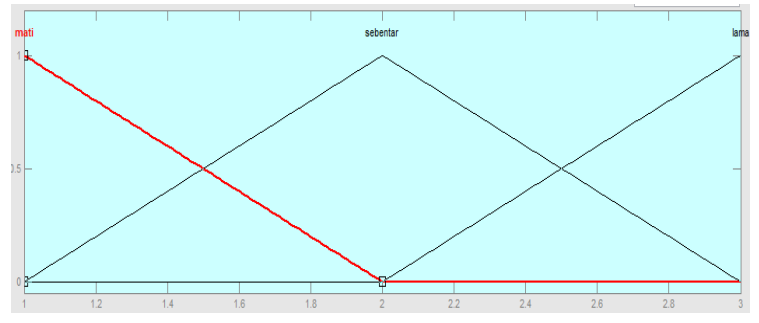

Tabel 3. Grafik keanggotaan kipas

\begin{tabular}{|c|c|c|}
\hline No & Kondisi & Derajat $\left({ }^{\circ} \mathrm{C}\right)$ \\
\hline 1 & Mati & $1-2$ \\
\hline 2 & Sebentar & $1-3$ \\
\hline 3 & Lama & $2-3$ \\
\hline
\end{tabular}

e. Grafik keanggotaan pemanas

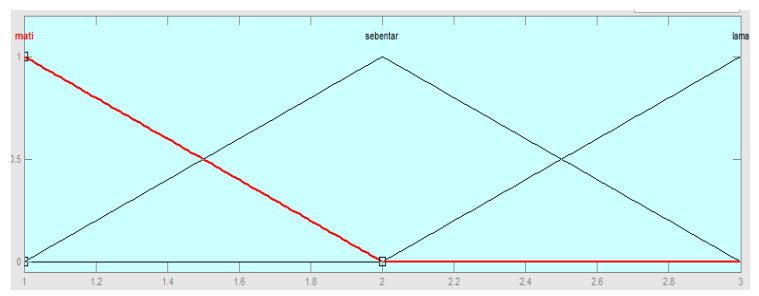

Tabel 4. Grafik keanggotaan pemanas

\begin{tabular}{|c|c|c|}
\hline No & Kondisi & Derajat $\left({ }^{\circ} \mathrm{C}\right)$ \\
\hline 1 & Mati & $1-2$ \\
\hline 2 & Sebentar & $1-3$ \\
\hline 3 & Lama & $2-3$ \\
\hline
\end{tabular}

\subsection{Blok Diagram Sistem}

Blok diagram adalah diagram dari sebuah sistem, di mana bagian sensor DHT11 sebagai alat masukan untuk mendeteksi suhu dan kelembaban, NODEMCU Sebagai alat pemrosesan, Kipas Pendingin dan Kipas Pemanas merupakan alat tambahan yang digunakan sebagai output. Proses kerja pada alat ini di tunjukkan pada Gambar 6

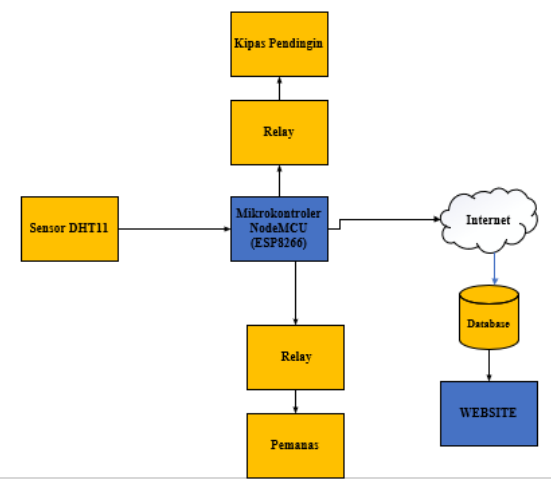

Gambar 6. Blok diagram sistem

\subsection{Flowchart Sistem}

Adapun alur proses Sistem dijelaskan pada Gambar 7.

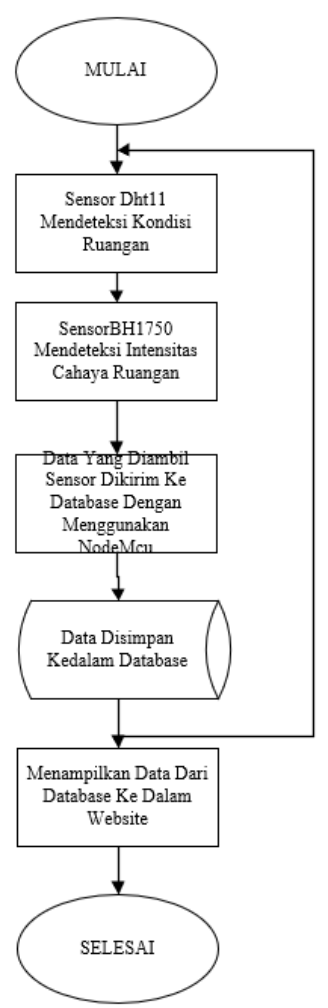

Gambar 7. Flowchart Sistem

Berdasarkan flowchart pada Gambar 7, sistem dimulai dengan menginisialisasi sensor DHT11 dimana sensor akan mendeteksi kondisi suhu dan kelembaban ruangan. Kemudian data akan diproses di mikrokontroler untuk dikirik ke database. Dan proses selanjutnya data akam ditampilkan pada halaman website.

\subsection{Flowchart Alat}

Adapun alur proses cara kerja alat dijelaskan pada gambar 8

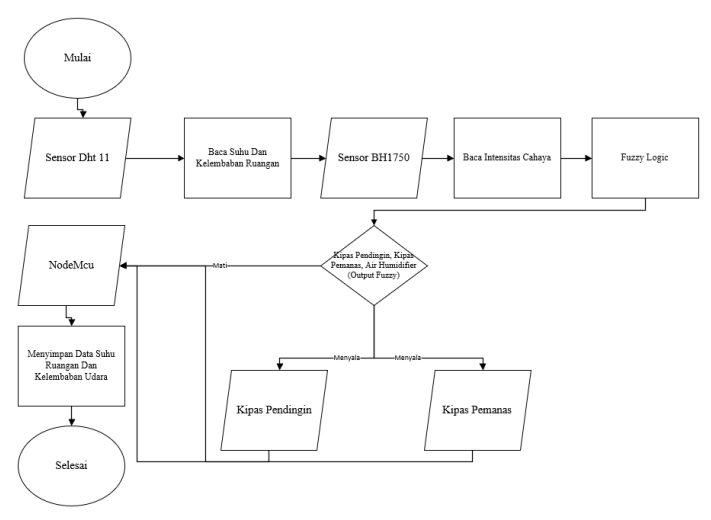

Gambar 8. Flowchart Alat 
Berdasarkan flowcchart pada Gambar 8, dimulai dengan sensor DHT11 akan mendeteksi suhu ruangan dan kelembaban udara. Setelah data suhu ruangan dan kelembaban udara didapatkan maka akan dilakukan proses fuzzy logic untuk menentukan kondisi kipas pendingin, kipas pemanas dan Air Humidifier. Jika hasil dari fuzzy logic pada kipas pendingin $>0$ maka kipas pendingin akan menyala, jika fuzzy logic pada kipas pemanas $>0$ maka kipas pendingin akan menyala dan jika fuzzy logic pada Air Humidifier $>0$ maka Air Humidifier akan menyala. Jika fuzzy logic $<0$ maka kipas pendingin, kipas pemanas dan air humidifier akan mati. Selanjutnya data akan dikirimkan ke database yang akan dilakukan oleh NODEMCU.

\section{IMPLEMENTASI DAN PENGUJIAN}

\subsection{Halaman Data Monitoring}

Halaman data monitoring merupakan halaman yang menunjukkan data suhu,kelembaban,status kipas, dan status pemanas.

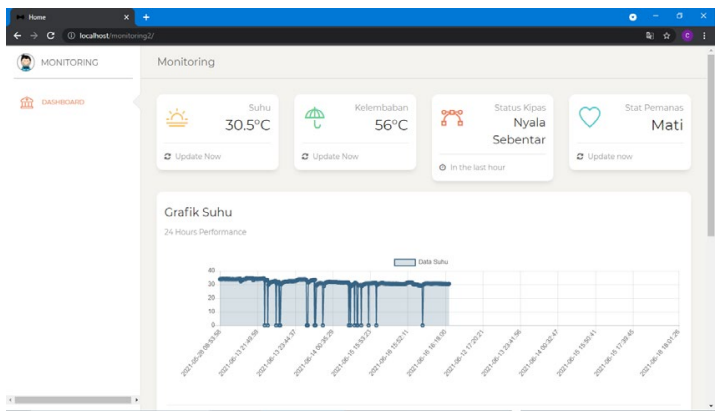

Gambar 9. Halaman Data Monitoring
Pada gambar 10, halaman home akan menampilkan data suhu, kelembaban, status pemanas, status kipas grafik suhu dan grafik kelembaban

\subsection{Tampilan Alat}

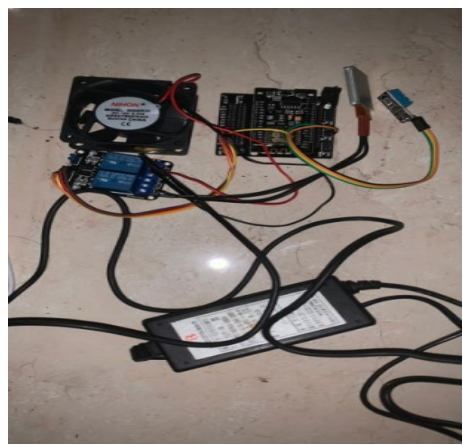

Gambar 10. Tampilan Alat

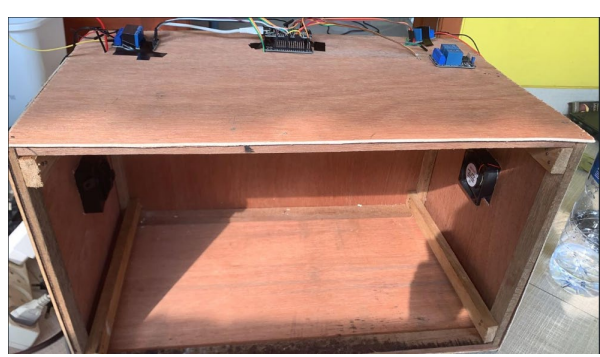

Gambar 11. Tampilan akhir alat

Pada gambar 11 merupakan tampilan awal alat yang belum sepenuhnya selesai, sedangkan pada gambar 12 merupakan tampilan alat yang sudah selesai.

\subsection{Pengujian Fungsional}

Tabel 5. Hasil pengujian Fungsional

\begin{tabular}{|c|c|c|c|c|c|}
\hline No & Tujuan & Input & Hasil yang diharapkan & Hasil sistem & $\begin{array}{c}\text { Hasil } \\
\text { pengujian }\end{array}$ \\
\hline 1 & $\begin{array}{l}\text { Menampilkan data } \\
\text { nilai suhu }\end{array}$ & $\begin{array}{l}\text { Nilai dari sensor } \\
\text { suhu DHT11 }\end{array}$ & $\begin{array}{l}\text { Sistem akan menampilkan nilai suhu dari } \\
\text { database yang diambil dari sensor. }\end{array}$ & $\begin{array}{l}\text { Tampilan pada panel web } \\
\text { dengan nilai suhu }\end{array}$ & Sesuai \\
\hline 2 & $\begin{array}{l}\text { Menampilkan data } \\
\text { nilai kelembaban }\end{array}$ & $\begin{array}{l}\text { Nilai dari sensor } \\
\text { kelembaban } \\
\text { DHT11 }\end{array}$ & $\begin{array}{c}\text { Sistem akan menampilkan nilai } \\
\text { kelembaban dari database yang diambil } \\
\text { dari sensor }\end{array}$ & $\begin{array}{l}\text { Tampilan pada panel web } \\
\text { dengan nilai kelembaban }\end{array}$ & Sesuai \\
\hline 3 & $\begin{array}{l}\text { Menampilakan data } \\
\text { status kondisi } \\
\text { pendingin }\end{array}$ & $\begin{array}{l}\text { Nilai dari keluaran } \\
\text { status pendingin } \\
\text { logika fuzzy }\end{array}$ & $\begin{array}{c}\text { Sistem akan menampilkan status yang di } \\
\text { konversi dari nilai logika fuzzy dari } \\
\text { database }\end{array}$ & $\begin{array}{l}\text { Tampilan pada panel web } \\
\text { dengan nilai status } \\
\text { pendingin }\end{array}$ & Sesuai \\
\hline 4 & $\begin{array}{l}\text { Menampilkan data } \\
\text { status kondisi } \\
\text { pemanas }\end{array}$ & $\begin{array}{l}\text { Nilai dari keluaran } \\
\text { status pemanas } \\
\text { logika fuzzy }\end{array}$ & $\begin{array}{c}\text { Sistem akan menampilkan status yang di } \\
\text { konversi dari nilai logika fuzzy dari } \\
\text { database }\end{array}$ & $\begin{array}{l}\text { Tampilan pada panel web } \\
\text { dengan nilai status pemanas }\end{array}$ & Sesuai \\
\hline 5 & $\begin{array}{l}\text { Menampilkan data } \\
\text { status kondisi } \\
\text { lampu }\end{array}$ & $\begin{array}{c}\text { Nilai dari sensor } \\
\text { intensitas cahaya } \\
\text { NH1750 } \\
\end{array}$ & $\begin{array}{c}\text { Sistem akan menampilkan status yang } \\
\text { dikonversi dari nilai database yang diambil } \\
\text { dari sensor }\end{array}$ & $\begin{array}{l}\text { Tampilan pada panel web } \\
\text { dengan nilai status lampu }\end{array}$ & Sesuai \\
\hline 6 & $\begin{array}{l}\text { Menampilkan data } \\
\text { grafik }\end{array}$ & $\begin{array}{l}\text { Nilai dari sensor } \\
\text { DHT11 }\end{array}$ & $\begin{array}{l}\text { Sistem akan menampilkan grafik dari nilai } \\
\text { sensor suhu dan kelembaban DHT11 sesuai } \\
\text { dengan waktu pengiriman data tersebut }\end{array}$ & $\begin{array}{c}\text { Tampilan grafik dengan } \\
\text { nilai suhu dan kelembaban } \\
\text { pada waktu yang tercatat } \\
\text { yang sudah diinput pada } \\
\text { database }\end{array}$ & Sesuai \\
\hline 7 & $\begin{array}{l}\text { Menampilkan } \\
\text { report }\end{array}$ & $\begin{array}{c}\text { Nilai dari sensor } \\
\text { DHT11, sensor } \\
\text { BH1750, Status } \\
\text { Pendingin, Status } \\
\text { Pemanas, Status } \\
\text { Lampu } \\
\end{array}$ & $\begin{array}{c}\text { Sistem akan menampilkan tabel yang } \\
\text { berisikan data dari nilai sensor DHT11, } \\
\text { sensor BH1750, Status Pendingin, Status } \\
\text { Pemanas, Status Lampu }\end{array}$ & $\begin{array}{l}\text { Tampilan tabel dengan nilai } \\
\text { suhu dan kelembaban, } \\
\text { status pendingin, status } \\
\text { pemanas, status lampu pada } \\
\text { waktu yang tercatat }\end{array}$ & Sesuai \\
\hline
\end{tabular}


Pengujian Black Box merupakan pengujian terhadap fungsional atau kegunaan dari aplikasi dengan cara membandingkan antara input dan output sistem tanpa pengetahuan dari isi program yang ada seperti pada tabel 5 diatas ini.

\subsection{Pengujian Pembacaan Sensor DHT11}

Pengujian pembacaan sensor suhu dilakukan dengan cara membandingkan pembacaan sensor dengan alat ukur suhu termometer. Dari hasil percobaan yang telah dilakukan seperti pada gambar 13, didapatkan hasil pembacaan seperti pada tabel 2 dibawah ini

Tabel 6. Hasil Pengujian Sensor DHT

\begin{tabular}{|c|c|c|c|c|}
\hline No & $\begin{array}{c}\text { Input } \\
\text { Suhu } \\
\left({ }^{\circ} \mathrm{C}\right)\end{array}$ & $\begin{array}{c}\text { Termometer } \\
\text { Analog }\end{array}$ & Error & Keakuratan \\
\hline 1 & 29.10 & 28.50 & $2.06 \%$ & $97.94 \%$ \\
\hline 2 & 29.40 & 29.00 & $1.36 \%$ & $98.64 \%$ \\
\hline 3 & 29.30 & 29.00 & $1.02 \%$ & $98.98 \%$ \\
\hline 4 & 29.20 & 29.50 & $1.027 \%$ & $98.98 \%$ \\
\hline 5 & 30.10 & 29.80 & $0.997 \%$ & $99.003 \%$ \\
\hline 6 & 30.00 & 29.80 & $0.667 \%$ & $99.333 \%$ \\
\hline 7 & 29.90 & 29.40 & $1.672 \%$ & $98.328 \%$ \\
\hline 8 & 29.90 & 28.40 & $1.672 \%$ & $98.328 \%$ \\
\hline 9 & 30.10 & 29.80 & $0.997 \%$ & $99.003 \%$ \\
\hline 10 & 29.40 & 29.00 & $1.361 \%$ & $98.639 \%$ \\
\hline
\end{tabular}

Dari hasil data pengujian pada tabel 6 maka didapatkan tingkat akurasi dan rata-rata error dari sensor suhu dan kelembaban DHT11, yaitu

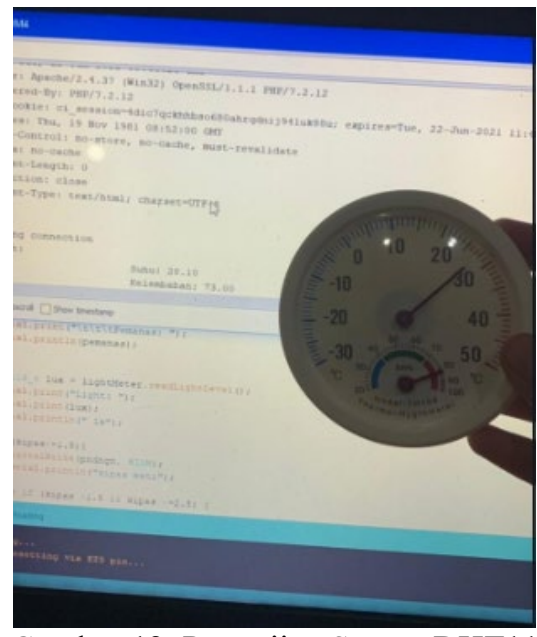

Gambar 12. Pengujian Sensor DHT1

Akurasi $=\frac{\sum \text { Akwrasi }}{\sum_{\text {Percobanan }}}$
Akurasi $=\frac{987.174}{10}=98.7174 \%$

Rata-rata error $=\frac{\sum \text { error }}{\sum \text { percobann }}$

Rata-rata error $=\frac{12.833}{10}=1.2833 \%$

Dari perhitungan diatas diketahui tingkat akurasi sensor DHT11 ini sebesar 98.7174\% dengan rata-rata error sebesar $1.2833 \%$.

\subsection{Pengujian Logika Fuzzy}

Dari hasil percobaan yang telah dilakukan, didapatkan hasil pembacaan seperti pada tabel 7 . dibawah ini

Tabel 7. Hasil Pengujian Logika Fuzzy

\begin{tabular}{|c|c|c|c|c|c|c|c|}
\hline \multirow{2}{*}{ No } & \multicolumn{2}{|r|}{ Input } & \multicolumn{2}{|c|}{ Diharapkan } & \multicolumn{2}{|c|}{ kenyataan } & \multirow{2}{*}{ Keterangan } \\
\hline & Suhu $\left({ }^{\circ} \mathrm{C}\right)$ & Kelembaban (\%) & Pendingin & Pemanas & Pendingin & Pemanas & \\
\hline 1 & 21.00 & 45.00 & Mati & Sebentar & Mati & Sebentar & Sesuai \\
\hline 2 & 24.00 & 45.00 & Mati & Sebentar & Mati & Sebentar & Sesuai \\
\hline 3 & 27.00 & 45.00 & Hidup Sebentar & Mati & Hidup Sebentar & Mati & Sesuai \\
\hline 4 & 30.00 & 45.00 & Hidup Sebentar & Mati & Hidup Sebentar & Mati & Sesuai \\
\hline 5 & 33.00 & 45.00 & Hidup lama & Mati & Hidup lama & Mati & Sesuai \\
\hline 6 & 21.00 & 55.00 & Mati & Sebentar & Mati & Sebentar & Sesuai \\
\hline 7 & 24.00 & 55.00 & Mati & Sebentar & Mati & Sebentar & Sesuai \\
\hline 8 & 27.00 & 55.00 & Hidup Sebentar & Mati & Hidup Sebentar & Mati & Sesuai \\
\hline 9 & 30.00 & 55.00 & Hidup Sebentar & Mati & Hidup sebentar & Mati & Sesuai \\
\hline 10 & 33.00 & 55.00 & Hidup lama & Mati & Hidup lama & Mati & Sesuai \\
\hline
\end{tabular}

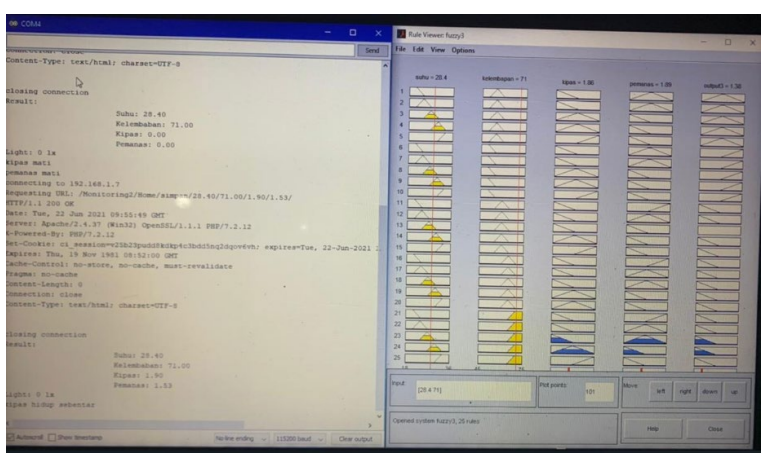

Gambar 14. Pengujian Logika Fuzzy
Dari hasil data pengujian pada tabel 7 maka didapatkan tingkat akurasi dari perancangan sistem monitoring suhu ternak ayam menggunakan metode fuzzy mamdani, yaitu :

$$
\begin{gathered}
\text { Akurasi }=\frac{\text { 7umiah Percoban yang sesuai }}{\text { 7umlah Percobaan }} \times 100 \% \\
\text { Akurasi }=\frac{10}{10} x 100 \%=100 \%
\end{gathered}
$$

Dari perhitungan diatas diketahui tingkat akurasi sistem ini sebesar 100\%. 


\subsection{Pengujian Sensor BH1750}

Tabel 8. Hasil pengujian Sensor BH1750

\begin{tabular}{|c|c|c|c|c|}
\hline No & $\begin{array}{c}\text { Input } \\
\text { Lux } \\
\text { (lux) }\end{array}$ & $\begin{array}{c}\text { Digital } \\
\text { Lux } \\
\text { Meter }\end{array}$ & Error & Keakuratan \\
\hline 1 & 18 & 18 & $0 \%$ & $100 \%$ \\
\hline 2 & 17 & 17 & $0 \%$ & $100 \%$ \\
\hline 3 & 10 & 9 & $10 \%$ & $90 \%$ \\
\hline 4 & 19 & 19 & $0 \%$ & $100 \%$ \\
\hline 5 & 22 & 23 & $4.348 \%$ & $95.652 \%$ \\
\hline 6 & 18 & 18 & $0 \%$ & $100 \%$ \\
\hline 7 & 24 & 24 & $0 \%$ & $100 \%$ \\
\hline 8 & 19 & 19 & $0 \%$ & $100 \%$ \\
\hline 9 & 19 & 19 & $0 \%$ & $100 \%$ \\
\hline 10 & 19 & 20 & $5 \%$ & $95 \%$ \\
\hline
\end{tabular}

Dari hasil pengujian pada tabel 8 didapatkan rata rata tingkat akurasi dan rata-rata error dari sensor $\mathrm{BH} 1750$, yaitu :

$$
\begin{aligned}
& \text { Akurasi }=\frac{\sum \text { Ahurasi }}{\sum \text { Percobanan }} \\
& \text { Akurasi }=\frac{980.652}{10}=98.0652 \% \\
& \text { Rata-rata error }=\frac{\sum \text { error }}{\sum \text { Percobann }} \\
& \text { Rata-rata error }=\frac{19.248}{10}=1.9348 \%
\end{aligned}
$$

Dari perhitungan diatas diketahui tingkat akurasi sensor BH1750 sebesar $98.0652 \%$ dan rata-rata error

\begin{tabular}{|c|c|c|c|c|c|}
\hline No & Pertanyaan & \multicolumn{4}{|c|}{ Hasil uji } \\
\hline 1. & $\begin{array}{lr}\text { Apakah Web } & \text { Dan } \\
\text { Otomatisasi } & \text { Pada } \\
\text { Monitoring Kandang } \\
\text { Ternak Ayam } \\
\text { Diperlukan? }\end{array}$ & 5 & 1 & 0 & 0 \\
\hline 2. & $\begin{array}{lr}\text { Apakah } & \text { Website } \\
\text { Monitoring } & \text { Kandang } \\
\text { Ternak Ayam } & \text { Petelur } \\
\text { Dapat Diakses } & \text { Dengan } \\
\text { Mudah? } & \\
\end{array}$ & 4 & 2 & 0 & 0 \\
\hline 3. & $\begin{array}{lr}\text { Apakah Informasi Yang } \\
\text { Ditampilkan } & \text { Pada } \\
\text { Halaman } & \text { Website } \\
\text { Monitoring } & \text { Kandang } \\
\text { Ayam Petelur } & \text { Mudah } \\
\text { Dipahami? } & \\
\end{array}$ & 3 & 3 & 0 & 0 \\
\hline 4. & $\begin{array}{l}\text { Apakah Penggunaan } \\
\text { Warna, Ukuran, Dan } \\
\text { Jenis Pada Font } \\
\text { Terlihat Dengan Jelas }\end{array}$ & 3 & 3 & 0 & 0 \\
\hline \multicolumn{2}{|c|}{ Jumlah } & 15 & 9 & 0 & 0 \\
\hline \multicolumn{2}{|c|}{ Total respon } & \multicolumn{4}{|c|}{24} \\
\hline
\end{tabular}
sebesar $1.9348 \%$.

\subsection{Pengujian User}

Tabel 9. Hasil pengujian Sensor BH1750

Pada tabel 9 pengujian user didapatkan dari beberapa pertanyaan dari beberapa orang dijabarkan dengan rumus sebagai berikut :

$$
\text { Persentase }=\frac{\text { Total skor perkolom }}{\text { Total kewelumban }} \times 100
$$

Didapatkan perhitungan persentase untuk keseluruhan pertanyaan kepada 6 pengguna sebagai berikut :

$$
\begin{aligned}
& \text { Sangat setuju }=\frac{15}{24} x 100=62,5 \% \\
& \text { Setuju }=\frac{9}{24} x 100=37,5 \% \\
& \text { Kurang setuju }=\frac{0}{0} x 100=0 \% \\
& \text { Tidak setuju }=\frac{0}{0} x 100=0 \%
\end{aligned}
$$

Sehingga dapat disimpulkan bahwa dari pengujian user, jumlah pemilihan terhadap sangat setuju sebanyak 15 , setuju sebanyak 9 , kurang setuju sebanyak 0 dan tidak setuju sebanyak 0 , atau jika dipersentasekan pemilihan sangat setuju sebesar $62,5 \%$ dan setuju sebesar $37,5 \%$.

\section{KESIMPULAN DAN SARAN}

\subsection{Kesimpulan}

Berdasarkan beberapa pengujian yang telah dilakukan didapatkan kesimpulan :

1. Hasil pengujian fungsional menunjukkan hasil 100 $\%$, artinya semua fitur web dapat berjalan pada google chrome, Microsoft Edge dan Uc Browser.

2. Hasil pengujian pembacaan sensor DHT11 menunjukkan tingkat akurasi sebesar 98.7174\% dengan rata-rata error sebesar $1.2833 \%$.

3. Hasil pengujian logika fuzzy menunjukkan hasil $100 \%$, artinya logika fuzzy dapat diterapkan dengan baik pada monitoring ternak ayam petelur.

4. Hasil pengujian sensor BH1750 menunjukkan tingkat akurasi sebesar $98.0652 \%$ dengan rata-rata error sebesar $1.9348 \%$

5. Hasil dari pengujian user didapatkan persentase untuk keseluruhan pertanyaan bahwa pemilihan terhadap sangat setuju $62.5 \%$ dan setuju $37.5 \%$.

\subsection{Saran}

Berdasarkan penelitian yang telah dilakukan, maka penulis dapat memberikan saran-saran untuk pengembangan selanjutnya antar lain :

1. Mengembangkan sistem monitoring pada pemrograman android.

2. Menambahkan notifikasi berupa pemberitahuan pada pemrograman android apabila suhu kurang atau melebihi suhu normal.

\section{DAFTAR PUSTAKA}

[1] Wulan Sari; Ika Ayu, "Sistem Monitoring Suhu dan Kelembaban Kandang bibit Ayam Ras Petelur (Gallus gallus) Menggunakan Telegram," Politek. Negeri Jember, 2020, [Online]. Available: https://sipora.polije.ac.id/2002/.

[2] E. Kustiawan, D. L. Rukmi, S. Imam, and S. O. Permadi, "STUDI INTENSITAS PENCAHAYAAN TERHADAP PUNCAK PRODUKSI AYAM PETELUR FASE LAYER DI UD. MAHAKARYA FARM 
BANYUWANGI," Politek. Negeri Jember, vol. 3, no. 1, pp. 14-18, 2019.

[3] R. F. Kafafi, "Rancang Bangun Monitoring Suhu Dan Kelemababan Kandang Guna Mempermudah Kinerja Peternak Berbasis Arduino," Mhs. Tek. Inform., vol. 3, no. 2, pp. 98-104, 2019.

[4] P. Huriati, A. Erianda, and F. Rozi, "APLIKASI MONITORING PERKEMBANGAN AYAM," vol. 2, no. 1, pp. 4-10, 2020.

[5] E. Murniyasih and A. Lawi, "Sistem Penjualan Online Dan Monitoring Otomatis Telur Ayam Ras Petelur," vol. 8, no. 3, pp. 184-193, 2017.

[6] A. Budi Laksono, "Rancang Bangun Sistem Pemberi Pakan Ayam Serta Monitoring," Univ. Islan Lamongan, vol. 2, 2017.
[7] N. I. Widiastuti and R. Susanto, "Kajian sistem monitoring dokumen akreditasi teknik informatika unikom," Maj. Ilm. UNIKOM, vol. 12, no. 2, pp. 195-202, 2014, doi: 10.34010/miu.v12i2.28.

[8] F. H. Sipatuhar, "Sistem Pengamatan Suhu Dan Kelembapan Pada Jamur Menggunakan Sensor DHT-11 Berbasis Atmega328P Dengan Tampilan Menggunakan LCD,” 2018.

[9] yolan dan mansuri, "Sistem Informasi Pariwisata Propinsi Nangroe Aceh Darussalam Berbasis Web," Jupiter, vol. 1, pp. 32-39, 2015, [Online]. Available: https://anzdoc.com/rancang-bangun-sisteminformasi-pilkada-berbasis-web-di-kabu.html. 